\title{
THE RELEVANCE OF SUBSIDIARY INITIATIVES FOR BRAZILIAN MULTINATIONALS
}

\author{
A RELEVÂNCIA DAS INICIATIVAS DE SUBSIDIÁRIAS PARA AS MULTINACIONAIS BRASILEIRAS
}

\section{ABSTRACT}

The purpose of this paper is to analyze relationship patterns between headquarters and subsidiaries of Brazilian Multinationals Enterprises (BrMNEs). The key construct for that investigation is Subsidiary Initiative, which comprises Subsidiary Entrepreneurial Orientation, Autonomy, Integration, Local Competitive Context and Business Network. A survey was carried out in a sample of 65 subsidiaries of 29 BrMNEs. The main outcome is that subsidiaries are highly integrated and receive Entrepreneurial Orientation from Headquarters (HQs), but Initiative is limited. Actually, the main determinants of subsidiary's initiatives are Local Context and Business Networking in the host country. This apparent paradox may be explained by what we call 'rebellious subsidiaries', which take initiatives based on their business environment and connections, regardless of their HQs' directions or delegation of autonomy.

\section{Felipe Mendes Borini}

Professor do Departamento de Administração, Escola Superior de Propaganda e Marketing - SP, Brasil fborini@espm.br

\section{Maria Tereza Leme Fleury}

Diretora da Escola de Administração de Empresas de São Paulo, Fundação Getulio Vargas - SP, Brasil e Professora da Faculdade de Economia, Administração e Contabilidade, Universidade de São Paulo - SP, Brasil

mtereza.fleury@fgv.br

\section{Afonso Carlos Corrêa Fleury}

Professor do Departamento de Engenharia de Produção da Escola Politécnica, Universidade de São Paulo - SP, Brasil

acfleury@usp.br

\section{Moacir de Miranda Oliveira Junior}

Professor da Faculdade de Economia, Administração e Contabilidade, Universidade de São Paulo - SP, Brasil

mirandaoliveira@usp.br

Recebido em 06.09.2008. Aprovado em 29.05.2009

Avaliado pelo sistema double blind review

Editor Científico: Rodrigo Bandeira-de-Mello

RESUMO O objetivo deste trabalho é analisar as subsidiárias de multinacionais brasileiras (BrMNEs), investigando as condições em que se desenvolvem iniciativas. Um survey foi realizado em uma amostra de 65 filiais, de 29 BrMNEs. O principal resultado é que a Iniciativa das filiais das BrMNEs ainda é limitada. As filiais são caracterizadas por elevada integração com a matriz e forte orientação empreendedora. Entretanto, os principais determinantes das iniciativas são o contexto competitivo e a rede de negócios no país estrangeiro. Este aparente paradoxo pode ser explicado por aquilo que estamos chamando de "filiais rebeldes", aquelas que tomam iniciativas com base no seu ambiente empresarial, independentemente do consentimento da matriz ou delegação de autonomia. Este resultado é suportado pela análise dos dados, que mostra que as filiais empreendedoras têm baixa autonomia concedida pela matriz.

KEYWORDS Initiatives, subsidiaries, Brazilian multinationals, internationalization, organizational strategy.

PALAVRAS-CHAVE Iniciativas, subsidiárias, multinacionais brasileiras, internacionalização, estratégia organizacional. 


\section{INTRODUCTION}

Research into subsidiaries of multinational enterprises (MNEs) has been multiplied over the last few years, revealing the phenomenon's complexity and diversity of analytical approaches (WERNER, 2002). The construct that is emerging as the most relevant in terms of conveying its different dimensions is "Subsidiary Initiative" (BIRKINSHAW, 1997).

This article aims at making a contribution to this debate, by focusing on the role of the subsidiaries of MNEs from emerging countries, particularly Brazilian Multinational. Brazilian Multinationals are international companies that originated from emerging markets and are engaged in outward Foreign Direct Investments (FDI), where they exercise effective control and undertake valueadding activities in one or more foreign countries (LUO, TUNG, 2007). Most studies on the role of subsidiaries and their evolution focus on MNEs from developed countries (PATERSON; BROCK, 2002; WERNER, 2002), since there were few MNEs from emerging countries. However, as the new Multinationals from emerging countries are becoming important global players (BCG, 2009; SANTISO, 2007), some pioneering studies about their subsidiaries recently appeared in the specialized literature, based on evidences or case studies (CUERVO-CAZURRA, 2008; BONAGLIA, GOLDSTEIN, 2007; MATHEWS, 2006; BARTLETT, GHOSHAL, 2000). Therefore, the originality of this article is associated not only to the development of a theme that is still rare in the literature but also to the novel methodological approach which was applied, based on quantitative data analysis.

This paper aims at adding to this debate; its objective is to analyze the role of the subsidiaries of Brazilian MNEs, by means of investigating the conditions under which these subsidiaries develop initiatives vis-à-vis their headquarters. Its original aspects are its focus, in an emerging country, on issues already explored in connection with developed countries and its quantitative methodology.

The initial assumption for the development of this article is that the role of subsidiaries of Brazilian MNEs should be different from the role of subsidiaries of developed countries. The fact that the Brazilian MNEs are late entrants into the international arena has strategic implications: since they are followers and originated in less developed countries, subsidiaries should play a key strategic role in their internationalization process. Therefore, we hypothesize a higher level of Initiative for the subsidiaries of Brazilian MNEs as compared to multinationals from developed countries. To test it, we depart from the same theoretical assumptions already used to study developed countries' MNEs and then analyze the case of Brazilian MNEs.

\section{THEORETICAL FRAMEWORK}

In the late 1990s, studies started to discuss subsidiaries from a less static, headquarters-centered point of view, focusing more on the emerging concept of the role of subsidiaries (BIRKINSHAW, MORRISON, 1995 BIRKINSHAW, 1997; BIRKINSHAW, HOOD, 1997 BIRKINSHAW, HOOD, JONSSON, 1998). Studies found that subsidiaries could take on different roles, depending on the function performed (FROST, BIRKINSHAW, ENSIGN, 2002; HOLM, PERDERESEN, 2000) and the resources and capabilities developed (BIRKINSHAW, HOOD, 1998; BIRKINSHAW, HOOD, JONSSON, 1998).

\section{The initiative dimension in the theory of subsidiaries}

Initiative is a discrete, proactive undertaking that advances a new way for the corporation to use and expand its resources (BIRKINSHAW, 1997). It is an entrepreneurial process, beginning with the identification of an opportunity and culminating in commitment of resources to that opportunity (BIRKINSHAW, 1997). This concept emerges to the extent that one considers that MNEs are organized as differentiated networks (BARTLETT, GHOSHAL, 1998; NOHRIA, GHOSHAL, 1997); it is a corporation with subsidiaries that adopt different strategies according to their competence and to their location and relationship with the headquarter. However, even when there is no network organization, the initiative may result from enterprising behavior that is not actively encouraged by senior management at headquarters, but, rather, performed by subordinates because of the senior management's inability to lead, direct and evaluate all the actions of its executive board (BOWER'S, 1970). There are cases in which an initiative may fail to be recognized by headquarters; yet it did occur, often with positive results that added to MNEs competitive advantage (BIRKINSHAW, 1996; BIRKINSHAW, 1997; BIRKINSHAW, HOOD, 1997; BIRKINSHAW, HOOD, 1998).

Burgelman (1983) proposes that initiatives can be coordinated by the corporation or generated within the subsidiary itself. The subsidiary operates in a local external market comprised of consumers, suppliers, competitors 
and regulating institutions. The initiatives that result from opportunities born out of the relation with these agents are called local market initiatives. The internal market consists of those elements that headquarters and other subsidiaries demand from the subsidiary under scrutiny. The demands may range from importing a product as a part of a global production chain to coordinating the activities of other foreign subsidiaries. Internal market initiatives result from opportunities created within the MNEs international network. The global market includes competitors, consumers and suppliers that do not belong to the two former markets; in other words, those elements which are located in other countries and that are not part of the MNE itself. The subsidiaries' global market might grow to the extent that the subsidiary starts to perform international activities or serve its headquarters' global clients. Global market initiatives result from opportunities that arise out of the relations with those foreign institutions (BIRKINSHAW, 1997). Therefore, three different types of initiatives might be identified: local initiatives, internal initiatives and global market initiatives (BIRKINSHAW, 1997).

Local market initiatives can be characterized by the development of new products or new markets, or new processes in the subsidiary's host country (BIRKINSHAW, 1997). The development of these initiatives is strongly linked to the subsidiary's innovative capacity, as well as to the existence of favorable circumstances in terms of competitive context (business environment and players) (PORTER, 1990) and strategic business partnerships (ANDERSSON, FORGREEN, HOLM, 2002). Two other factors are important for the initiatives: autonomy, according to Young and Tavares (2004), is the possibility available and acquired of the subsidiary take decisions in regards its on interest, and integration, according to Bartlett and Ghoshal (1998), is the capacity of subsidiaries and headquarters to work together with the same vision and objectives changing experiences. Initially, it was assumed that the development of these initiatives might be associated with a high degree of local decision-making autonomy and strong integration in terms of shared values and of headquarters-subsidiary communication (NOHRIA, GHOSHAL, 1997). Subsequent studies showed that these initiatives, when they first start being developed, are associated with high autonomy and high integration, but after some time has passed after the development of the initiatives, the most appropriate behavior for their recognition by headquarters would be a reduction of autonomy coupled with higher integration (BIRKINSHAW, 1997).
Internal market initiatives are characterized by the redistribution of activities to those subsidiaries that enjoy the requisite competence to carry out these activities, and involve transferring processes from headquarters to the subsidiaries, allocating a greater amount of investment to subsidiaries as a reward for successful results, or still, new R\&D or production process investments (BIRKINSHAW, 1997). Internal market initiatives are linked to high subsidiary credibility vis-à-vis headquarters, which is a function of the high degree of integration (BIRKINSHAW, 1997).

The global market initiatives are characterized by expansion of existing international responsibility, reconfiguration of domestic operations into international ones or even the creation of international activities (BIRKINSHAW, 1997). These initiatives are associated with high autonomy and low integration. Low integration does not mean a total lack of association between the subsidiary and the MNE, but, rather, a more formal relation post factum information exchange, explained, in part, by the striking presence of international responsibility as an essential global initiative factor (BIRKINSHAW, 1997). The competitive context and the business networks perform special roles. The network is very important because it can enable inclusion in a global production chain through its relationship with clients abroad. On the other hand, the domestic context may seem to have been put on a backburner because of international relationships. However, the availability of skilled labor and national competitiveness factors are important for expanding subsidiaries' innovation capacity through the support of political and economic institutions.

Exhibit 1 summarizes the types of initiatives and the factors typically associated with each one of them.

\section{Initiative dimension at subsidiaries of MNEs from emerging markets}

Assuming, therefore, that the initiatives are important for the subsidiaries of multinationals (BIRKINSHAW, 1997) and are fundamental elements for the understanding of the functions of these subsidiaries and for the construction of competitive advantage (BIRKINSHAW, HOOD, JONSSON, 1998) and also determine the evolution of the subsidiary role (BIRKINSHAW, HOOD, 1998), questions concerning these issues in the context of Brazilian MNEs arise.

Bartlett and Ghoshal (2000) described and exemplified the main characteristics to be developed by corporations in order to become a global player. The authors discuss the strategic positioning of competitors from emerging 
countries in the value curve. The authors propose that higher technology and/or marketing complexity, the higher margin, meaning that MNEs from emerging markets must invest in products and services that are either more complex technologically or in market terms, thereby circumventing the pressure of the low margins that commodity-type products and services tend to yield.

Therefore, if we consider Brazilian MNEs like followers, in order to be able to compete vis-à-vis the global market's major players, need to climb up the value curve be competing with products born out of new technologies and that offer greater added value; alternatively, they must break the rules of the game. In sum, Brazilian MNEs depend of innovation.

Meanwhile, the Brazilian multinational besides being followers suffer like all other emerging multinationals for being born in the wrong place (MATHEWS, 2006).

Sull and Escobari (2004) have studied Latin American enterprises and their difficulties in facing globalization. The authors have indicated that despite difficulties, a few Latin American enterprises have attained leadership in their industries and they indicated three steps for successful internationalization: commitment to a global mindset, involvement in daring decisions in order to make this commitment irreversible and realignment of the entire company to compete on a global scale. They must innovate within market niches on an incremental basis, or innovate radically in mature markets; or, additionally, maintain high flexibility, aligning themselves with daring (innovative) undertakings in order to survive in turbulent and highly competitive markets.

In sum, when we consider Brazilian MNEs to be born in a wrong country the only way to win in the world competition is to innovate. Thus, Brazilian MNEs are dependent of innovation and the development of subsidiary initiatives are fundamental to overcome the set of multinationals; according to Birkinshaw and Fry (1998), initiatives are the main source of own subsidiary innovation.

\section{PROPOSITIONS}

\section{Subsidiary entrepreneurial orientation (SE0)}

Entrepreneurship is associated with Schumpeter's definition (1934): a predisposition to create new things and take risks with one's own resources. Subsidiary Entrepreneurial Orientation (SEO) refers to a general positive attitude at the multinational regarding new business opportunities that may be led and implemented locally; which means, in particular, a certain level of trust and freedom not only of human but also of social capital, which will allow a degree of autonomy to the subsidiary making decisions and running risks and the headquarters' support (BIRKINSHAW, 1997). Entrepreneurial activities consist not only in creating new businesses, or a new mix of products and processes, but in maintaining a general proactive attitude in risky decisionmaking environments, using direct access to people or departments (BIRKINSHAW, 1997). Thus, SEO can be characterized by the firm's predisposition to run risks, or, at least, to provide support for the running of certain types of risk. If the multinational stimulate subsidiaries to run risk there is more probability of subsidiary develop own initiatives. In this way SEO is a global guideline for entrepreneurial orientation, meanwhile initiative is a consequence of this guideline if the subsidiary is able to develop own entrepreneurial capacity.

SEO is, in certain way, essential for subsidiaries to achieve development of initiatives. It is clear that, without the required degrees of freedom and support to start initiatives, sooner or later the subsidiary will lose the initiatives and SEO may disappear (BIRKINSHAW, 1997; BIRKINSHAW E HOOD, 1998). Even if the firm's founder is an entrepreneur, his(her) views are bound to fail if they lack the support of intrapreneurs with responsibility for the execution of the overall vision and for the creation of complementary visions that support the enterprise over the course of time (FILION, 2006). That is why it is important to have not only the incentive of the firm's upper management, but also to benefit from the subsidiary's upper management experience

Exhibit 1 - Types of initiatives and the factors associated with each one of them

\begin{tabular}{|c|c|c|c|c|c|}
\hline INITIATIVE & SEO & AUTONOMY & INTEGRATION & CONTEXT & NETWORK \\
\hline Local & Strong & Strong (start) Weak (end) & Weak (end) Strong (start) & Strong & Strong \\
\hline Internal & Strong & Weak & Strong & Moderate & Moderate \\
\hline Global & Strong & Strong & Weak & Moderate & High \\
\hline
\end{tabular}


and commitment to an entrepreneurial orientation. One example of this is the Brazilian MNE Odebrecht.

The encouragement of internal entrepreneurship, or intra-entrepreneurship, which is evident in the organization, intensely aids the consolidation of this belief. Thus, the Odebrecht management model delegates decision-making power to the so-called partner entrepreneurs, functional staff with entrepreneurial characteristics, responsible for prospecting and consolidating global business, disseminating information and knowledge to the network and anticipating the requirements of the competitive environment (Oliveira Jr and Mazzola, 2007). Therefore:

Proposition 1: The greater the entrepreneurial orientation of the subsidiaries of Brazilian MNEs, the more present their initiatives will be.

\section{Autonomy}

First of all, it is necessary to differentiate between entrepreneurship and autonomy. The two concepts are not equal. Entrepreneurship is the competence of create new things and take risks with one's own resources. On the other hand, autonomy concerns the headquarters and subsidiary relationships and refers to the degree of freedom that the subsidiary has in order to make decisions recognized by the headquarters (YOUNG, TAVARES, 2004).

Autonomy can become manifest in different ways. One of them is related with the issue of products and markets and is characterized by granting the subsidiary authorization to alter the design of the products or services offered, introduce new products or services and enter new markets as a result of its own decisions (BIRKINSHAW, 1996). This factor is very important for Brazilian MNEs, as one of the main alternatives for circumventing the lowcost and commoditization trap is to exploit market niches or create new markets, these being typical local market initiatives. A greater degree of autonomy would facilitate the realization of these opportunities within a competitive time frame (SULL, ESOBARI, 2005).

Another facet of autonomy is connected with the organization's configuration and is characterized by the capacity to deliberately decide upon outsourcing, or changes in the production processes or other managerial practices, all of which call for greater subsidiary freedom to hire its senior executives and to define a suitable allocation of its resources (BIRKINSHAW, 1996). Freedom to make these operating decisions provides the company with the advantage of implementing consecutive operational improvements (SULL, ESCOBARI, 2005) and of adjusting itself to the environment faster than external competitors, in the pursuit of local market initiatives, or of enhancing its efficiency vis-à-vis the internal competition amongst subsidiaries, thereby canvassing advantages in the pursuit of international market initiatives.

Therefore, high autonomy appears to be an essential requirement for Brazilian MNEs, given their subsidiaries' limited exposure in the global market. Of course, in order to obtain recognition for their initiative, Brazilian multinationals' subsidiaries should gradually reconcile a lower degree of autonomy with a higher degree of integration; however, it seems premature to require this limited autonomy from the Brazilian MNEs.

However, what the Brazilian multinationals' cases show is that a high degree of autonomy is a major challenge they must face in going forward. The Brazilian MNEs are beginners in the global market. It was only in the late 1990s that the internationalization of Brazilian enterprises acquired pace and consistency (FLEURY and others, 2007). Given this recent internationalization, control over foreign operations is still very strong, which is explained by the fact that subsidiaries function as a unit of the corporation, in line with the assumption of extending products and businesses to subsidiaries (VERNON, 1966, DUNNING, 1993) and with a strong cognitive limitation in relation to the foreign country (JOHANSON, VAHLNE, 1977).

Thus, a major dilemma hovers over Brazilian MNEs subsidiaries. On one hand, their autonomy tends to be low, as they are only in the early stages of internationalization; on the other hand, a competitive position in the global market can only be built through initiatives of the subsidiaries themselves, which calls for more autonomy. This being the case, one expects the following:

Proposition 2: The greater the degree of Brazilian MNEs subsidiaries' autonomy, the more present their initiatives will be.

\section{Integration}

Headquarters-subsidiaries integration is correlated with communication amongst them and with the credibility of the subsidiary's executive board vis-à-vis its headquarters (NOHRIA, GHOSHAL, 1997).

A better understanding of headquarters-subsidiary integration can be obtained through a counterpoint with autonomy. As mentioned earlier, a duality is at play between integration and autonomy. The initiatives oscillate between: (1) more integration and less autonomy for internal market initiatives; (2) less integration and more autonomy for global market initiatives; and (3) a 
continuum of more autonomy and less integration, until less integration and more autonomy are reached in the case of local market initiatives (BIRKINSHAW, HOOD, JONSSON, 1998).

However, the integration versus autonomy duality does not need to exist; in other words, alternating a high and a low degree of integration does not necessarily lead to a low/high degree of autonomy (NOHRIA, GHOSHAL, 1997).

On of the points that integration consists of is the work relation between headquarters and the subsidiaries and the exchange of information. The greater the work relation and information exchange, the greater the integration, which does not necessarily mean less autonomy, because this form of communication between headquarters and subsidiaries allows organizational values to be more easily shared, thus reducing the distance between the headquarters' executives and the subsidiaries and viceversa. Thus, strong integration ensures that headquarters has greater trust in its subsidiaries, also enabling values, such as the entrepreneurial culture, to be disseminated across the corporate network. At the same time, this integration guarantees that the initiatives, regardless of their type, are more easily accepted or supported by headquarters. Therefore, it is to be expected that the greater the integration, the better the environment at the subsidiaries in terms of initiative development, in particular among the subsidiaries of Brazilian MNEs only recently internationalized (NOHRIA, GHOSHAL, 1997).

Yet another facet of integration is the trust delegated by headquarters and the credibility of the subsidiaries' executives. Once again, the autonomy versus integration duality may not exist; on the contrary, one would expect that in an environment of greater trust and credibility, greater autonomy should be granted, or, at the very least, greater headquarters' support for subsidiariy's activities and initiatives. Given that Brazilian MNEs subsidiaries should be governed by innovative activities the greater the trust and credibility, it follows that the probability of initiatives being present should also be greater (BIRKINSHAW, HOOD, JONSSON, 1998). Therefore:

Proposition 3. The initiatives of Brazilian MNEs subsidiaries are associated with high headquarterssubsidiary integration.

\section{The competitive context}

The roles of foreign-owned subsidiary companies (i.e. the activities that they have responsibility for in the multinational corporation) vary according to such contingencies as the local environment. By considering productivity aspects, classical theory explains the success of countries based on land and labor; in other words, countries obtain competitive advantage in areas of intensive use of resources that they have in large supply. On the other hand the theory of Competitive Advantage of Nations (PORTER, 1990) tries to explain why a given country has local conditions that guarantees competitiveness not so much based on costs, but in quality, innovation, and uniqueness, innovation being the element that allows the development of competitive advantage.

According to Porter (1990), countries have four conditions that, when integrated, allow for building national sustainable competitive advantage. These conditions are rivalry of competition, intensity of demand, correlated and support industries, and conditions related to production factors. These conditions (here denominate competitive context) define the vertexes of the national advantage diamond that represents the essential environmental conditions for innovative countries.

Therefore, whenever trying to analyze the relationship between multinational corporations (MNC's) subsidiaries and national development conditions, one must look for the fact that once they become part of the national context, subsidiaries of MNEs may have access to innovations, and specific talents and knowledge (BARTLETT, GHOSHAL, 1998). In addition, 'sharing' the conditions offered by the national diamonds may help to transfer activities of higher value (e.g. R\&D; regional leadership) from headquarters to the country of the subsidiaries (FROST, 2001; FROST, BIRKINSHAW, ENSIGN, 2002). This means that countries with a strong competitive context are favorable for local or global initiatives due to market opportunity, especially the exploitation of market niches.

At the same time, the possibility of exploiting resources or new technologies in host countries, this being one of the drivers of multinationals from emerging economies, increases the possibilities of subsidiaries winning the internal competition for an internal initiative. Hence we may expect that:

Proposition 4: The subsidiary's presence in dynamic competitive contexts is positively connected with the presence of initiatives within the subsidiaries.

\section{Business network}

The Nordic school of international business is the main reference when the subject is business networks in the area of international business. The relationship networks in foreign markets play a major role with regard to the development of subsidiaries' initiatives (JOHANSON, 
MATTSSON, 1988). Moreover, when one talks about relationship networks, the reference concerns both external network and internal ones. An external network is the fruit of the subsidiary's relationship with business partners such as suppliers, research institutions and advertising agencies, among others (ANDERSSON, FORSGREN, HOLM, 2002). An internal network results from the subsidiary's relationship with other subsidiaries (BJORKMAN, FORSGREN, 2000).

According to these scholars, the greater the embeddedness of a subsidiary in the foreign country's networks (ANDERSSON, FORSGREN, HOLM, 2002), the greater its possibility of gaining access to knowledge capable of assuring the development of local or global initiatives. However, as the company becomes increasingly embedded in the local market, the weaker its integration with the intra-organizational network, which implies in a lower possibility of alignment and recognition of the initiative (ANDERSSON, FORSGREN, 2006). The fact that the subsidiary is strongly embedded in the foreign country's network, on one hand, allows access to tacit and complex knowledge that would not be acquired otherwise; but, on the other hand, it makes it more difficult for this knowledge to be transferred internally to the headquarters or other subsidiaries (ANDERSSON, FORSGREN, 2006).

From the point of view of the corporation, if the objective is to use the subsidiary as a source of competitive advantage, the most appropriate conduct would be to maintain a subsidiary with strong intra-organizational integration, but without a strong embeddedness in its location. However, for the subsidiary, it would be preferable to have strong integration with the local network, which implies in paying the corporation less attention, while maintaining a higher chance of developing initiatives and pursuing strategic importance. Thus, the situation is paradoxical (ANDERSSON, FORSGREN, 2006).

In other words, if the subsidiary is not integrated into the local business networks, but is integrated into the corporate network, it might acquire more knowledge, but this knowledge would probably be less innovative than it would be if the subsidiary were more integrated locally.

However, if the subsidiary is integrated into the foreign country's business network, there is a greater possibility of developing innovative knowledge with great potential for scarcity, difficult to imitate and value-generating; hence, there is also a greater competitive advantage for the subsidiary with regard to the local and the global markets (for the MNEs progress along the value scale). Still, this does not translate, necessarily, into greater subsidiary international and strategic responsibility, because its initiatives may not be recognized by the corporation due to low integration (ANDERSSON, FORSGREN, 2006).

It is clear, therefore, that the more integrated with the corporate network the subsidiary is, the greater the possibility of its making the most of internal initiatives; in turn, the more embedded into the external business network of the host country, the greater the possibility of developing a global or local initiative. Herein lies the core question: whether subsidiaries should or should not seek out business networks for the development of initiatives (ANDERSSON, FORSGREN, 2006).

Andersson and Forsgren (2006) give us some clues for finding a solution to this issue. According to them, a subsidiary can vary its degree of integration into the corporate network and the external network. One infers from this that a subsidiary totally embedded in the external network and with only weak links to the corporate network would have major possibilities of developing, for example, local initiatives born out of the relationship with the network; this knowledge, however, would not constitute a competitive advantage because of its lack of alignment with the global corporate strategy. At this point in time, it would be appropriate for the firm to modify its relationship and to acquire a stronger integration with the internal network than with the external one. This requires a high capacity for maintaining the flexibility of operations and a sense of opportunity (SULL and ESCOBARI, 2005) that are typical of the key requirements for followers' competitiveness. However, the lack of this flexibility might cause the subsidiary to waste initiatives and competitive advantage creation visà-vis the competition.

Proposition 5: The presence of the subsidiary in foreign countries' business networks is positively correlated with the presence of initiatives in the subsidiaries.

\section{METHODOLOGY}

In our survey, the research universe consisted of Brazilian multinationals (BrMNEs) with manufacturing activities or that supplied technological services, with operations abroad. In December 2006, 42 Brazilian enterprises were identified as having operations abroad, thus qualifying as multinationals. That number comprised a diversity of firms ranging from the natural-resources based firms to firms operating in the services sector, such as Engineering and IT.

The research process about the subsidiaries of Brazilian MNEs was structured in two parts. Initially, a survey 
was prepared focusing on "Strategies and Competences of Brazilian Multinationals" to be answered by the CEO or the person responsible for the area of International Operations. The questionnaire was prepared based on formerly existing research instruments (BIRKINSHAW, HOOD; JONSSON, 1998), and pre-tested in two BrMNEs.

29 out of the 42 firms responded to the questionnaire. From the 13 missing firms, just two were of major importance; they were not allowed to respond because they were on the brink of important acquisitions and thus unable to open information for the general public.

The second stage consisted of having the firms' headquarters send a custom-designed questionnaire to their subsidiaries. This stage was dependent of the companies that answered the first stage. Consequently only 29 companies indicate yours subsidiaries. The 29 BrMNEs sent this questionnaire to a total of 93 subsidiaries abroad. In other words, each headquarters involved an average of three subsidiaries, though some involved as many as eight subsidiaries whereas others involved only one. 65 out of the 93 subsidiaries involved provided a response by letter or through the electronic questionnaire found in the project's website. The rate of response was therefore $70 \%$.

\section{Constructing the variables}

All the responses about the variables were constructed on the basis of a 5-point Likert scale. The dependent variable is Initiative (BIRKINSHAW, 1997) formed by the following indicators: a) New products developed and sold internationally; b) Expansion of existing international responsibility; c) Successful investment results in that country; d) Transfer of processes by the subsidiary to foreign countries; e) Acquisition of domestic companies conducted by the subsidiary; f) New international business activities created in the country; g) Increase of the product lines adopted internationally; h) New investments in $R \& D$ or production processes; i) Reconfiguration of the Brazilian operations from domestic to international (Cronbach's Alpha of 0.808).

The independent variable Autonomy (BIRKINSHAW, HOOD; JONSSON, 1998) was constructed through the following indicators: a) Change in the design of the products / services offered; b) Outsourcing to third parties of the main production/service; c) Entry into new markets within the country; d) Introduction of new products/ services; e) Changes in the production process; g) Hiring of subsidiaries' senior executives; g) Annual budget approval; h) Organizational changes at the subsidiary (Cronbach's Alpha is 0,780).
The independent variable Entrepreneurial Orientation (BIRKINSHAW, 1997) was constructed through the following indicators: a) Senior management's support for entrepreneurial activities; b) Experience with innovation activities; c) Individual risk decisions; d) Incentive for taking calculated risks; e) Risk taking being seen as positive (Cronbach's Alpha is 0.879).

The independent variable Integration (BIRKINSHAW, HOOD; JONSSON, 1998) was constructed through the following indicators: a) A strong work relation; b) Trust delegated to the subsidiary; c) Information exchange; d) Headquarters understanding the subsidiary's competencies; e) Credibility of the subsidiary's executives (Cronbach's Alpha is 0.871).

The independent variable Local Context (BIRKINSHAW, HOOD; JONSSON, 1998) was constructed by the following indicators: a) Proactivity of the national government; b) Degree of competition in the country; c) Suppliers' capacities and qualities; d) Relationship between buyers and suppliers; e) Stability of the political / legal environment; f) Existence of major research centers; g) Speed of product innovation; h) Local consumption patterns; i) Business support institutions; j) Change gradient of market demand; k) Manpower qualifications. (Cronbach's Alpha is 0.859).

The independent variable Business Network (ANDERSSON; FORSGREN, 2002) was constructed through the following indicators: a) Other subsidiaries abroad of the firm; b) Other firms' R\&D units; c) Other firms' engineering companies; d) Specific research institutes or universities; d) Corporate R\&D unit (abroad); f) Preferred corporate suppliers within the country; h) Suppliers to specific markets. (Cronbach's Alpha is 0.811).

\section{RESULTS}

In order to test the propositions, we conducted a linear regression for the dependent variable Initiative. All the variables in question posted normality at the 0.05 significance level. The distribution of means and standard deviation are shown on Table 1.

As for Initiatives, the results show that in general they are few. Only $7 \%$ of the subsidiaries reflected strong agreement regarding the presence of initiatives and more than $15 \%$ reflected only moderate agreement. Therefore, initiatives are still limited among BrMNEs. The table shows that the subsidiaries consider Local Context as a factor with a stronger influence. Entrepreneurial 
Orientation and Integration between headquarters and the subsidiaries are characteristics found among most of the subsidiaries, indicating that the relationship's trust and credibility foster the dissemination of an entrepreneurial culture. In turn, the influence of Business Networks is still under-exploited by subsidiaries, which, by and large, enjoy only little autonomy.

According to the analysis shown on Table 1 , the results indicate that the Local Competitive Context is correlated with the Business Networks (which would also be local or articulated in that location), as expected. However, the inclusion in Business Networks has a relation with the subsidiaries' Autonomy. The greater the Autonomy, the greater the subsidiaries' predisposition to join Business Networks abroad and to obtain initiatives from this relation is. However, this Networks membership is only modest, due to BrMNEs' low level of Autonomy.

Another striking point is the positive and moderate relation between Integration - headquarters and subsidiaries - aligned with an Entrepreneurial Orientation The strong Integration found in most subsidiaries indicates that their executives' credibility is high, but that this does not lead to Autonomy to make decisions. Although credibility is high, headquarters' executives prefer a strong work relationship, permeated by a strong exchange of information, instead of granting subsidiaries autonomy. This suggests a strong inclination toward the dissemination of the entrepreneurial culture of the multinational corporation across the network, as reflected in the subsidiaries' high Entrepreneurial Orientation, coupled with a restriction of Initiatives, as the realization of Entrepreneurial Orientation is limited by low Autonomy.

The proposed model was tested by means of the linear regression presented on Table 2. The model's colinearity was measured using tests of Tolerance and VIF smaller than five, ensuring the absence of multicolinearity among the variables (HAIR, 2005).

Table 1 - Descriptive statistics and correlation

\begin{tabular}{|l|c|c|c|c|c|c|c|c|}
\hline & N & MEAN & STD. DEVIATION & 1 & 2 & 3 & 4 & 5 \\
\hline Network & 65 & 1,96 & 1,08 & & & & \\
Context & 65 & 3,37 &, 728 &, $321 *$ & & & \\
Autonomy & 65 & 2,31 &, 944 &, $286 *$ &, 022 & & \\
Integration & 65 & 3,91 &, 952 &, 225 &, 102 &, 136 & \\
Entrepreneural & 65 & 3,82 & 1,00 &, 237 &, 124 &, 031 &, $504 * *$ \\
\hline Initiatives & 65 & 2,40 & 1,22 &, $454 * *$ &, $403 * *$ &, 197 &, 110 &, 155 \\
\hline
\end{tabular}

Note: $* p<0,05 ; * * p<0,01$

Table 2 - Linear regression models

\begin{tabular}{l|cc} 
& INITIATIVE & VIF \\
\hline (Constant) & $-0,360$ & 1,280 \\
Network & $0,368^{* *}$ & 1,125 \\
Context & $0,491^{* *}$ & 1,110 \\
Autonomy & 0,131 & 1,270 \\
Integration & $-0,046$ & 1,381 \\
Entrepreneurial orientation & 0,069 & \\
\hline R Square & 0,293 & \\
Adjusted R Square & 0,238 & \\
F & $4,83^{* *}$ &
\end{tabular}

Note: $* * p<0,01 ; * p<0,05$ 
The factors that explain the development of the Initiatives are the Business Networks and the local competitive Context. In other words, for the BrMNEs' subsidiaries, the essential Initiative development factors result directly from the competitive context within which the subsidiary operates, as well as from its membership in the foreign country's Business Network. Though the Local Context is favorable for most subsidiaries and a factor that they strongly exploit, Integration into the foreign country's Business Network is still modest where most subsidiaries are concerned; this can be explained by the low degree of Autonomy. Only a few subsidiaries are able to use the Business Network to increase the Initiatives.

The propositions about the relation between Entrepreneurial Orientation, Integration and Autonomy and subsidiaries' Initiatives were not supported. It is important to stress that although Entrepreneurial Orientation and Integration have no direct relation with the formation of Initiatives, the two factors are relevant in most BrMNEs' subsidiaries. However, the results also show that Integration, besides having no direct influence upon the Initiatives, also has an inverse relation with the presence of Initiatives in the subsidiaries.

Thus, results only confirm propositions 4 and 5 . In the section below, we will discuss these results' implications.

\section{DISCUSSION}

\section{The type of initiative of Brazilian MNEs subsidiaries}

The determinants of subsidiaries' initiatives are Local Context and Business Network. Within the rationale of the subsidiaries' different markets, the results show a strong tendency toward the development of Local Market Initiatives and, on a secondary level, the development of Global Market Initiatives.

This inclination toward local and global market initiatives rather than internal initiatives can be plausibly explained by the acceptance of the condition of their Brazilian MNEs parent companies' recent entry into the international market and the need for these companies to avoid the trap of being low cost or commodity producers.

These firms, in order to find their own niche in the global market, must pursue market niches and opportunities to move up the value curve. The example of Haier, a Chinese white goods firm that entered the US market, which is strongly dominated by GE and Whirlpool, illustrates this point. Haier's major challenge consisted of overcoming the leading brands. Their solution was to exploit the opportunity of serving dissatisfied customers better. The initiative consisted of transferring $R \& D$ to the US, which allowed them to customize their offerings better due to local production, taking advantage of the favorable competitive environment to stop competing in the lower-priced market and moving up the value curve (LIU, LI, 2002).

Insertion into the business network also makes it possible for Brazilian MNEs to climb up the value curve and engage in unique benchmarking. An example of this is Sabó, a Brazilian autoparts MNE. In 1993, it acquired Kaco, a German firm specializing in the sale of retainers. Kaco's acquisition, coupled with a manufacturing strategy of outsourcing components, allowed Sabó to come close to the major production centers and to important customers on the cutting edge of technology. This in turn enabled Sabó, through Kaco, to take part in the development of new automotive technologies, thereby increasing its technological competencies and its production chain relationship competencies (RAMAMURTI, 2008).

\section{The dynamics of initiative formation}

The subsidiaries are characterized by high Integration with their headquarters as well as by their Entrepreneurial Orientation. However, this is not a determinant of subsidiaries' Initiatives. The results show that Integration is associated with Entrepreneurial Orientation but inversely correlated with Initiatives.

Given that the preponderant Initiatives are not external market (local and global) ones, one would expect an absence of a direct relation between Initiatives and Integration, given that with regard to Local Market Initiatives, Integration is only preponderant in a secondary stage, while in Global Market Initiatives, Integration plays a less important role.

However, it is worth highlighting the relation between Integration and Entrepreneurial Orientation. The enhanced reliability, credibility and understanding of the operations of Brazilian MNEs' subsidiaries guarantee that headquarters provide greater support for entrepreneurial activities. Therefore, Integration is important for the Initiatives, though indirectly rather than directly related, as support for the establishment of an entrepreneurial culture in the subsidiaries.

In the case of Brazilian MNEs' subsidiaries, Entrepreneurial Orientation did not appear to be directly related with Initiatives, though the subsidiaries largely showed a strong Entrepreneurial Orientation; in the model, this variable is positively associated with the creation of initiatives. All of which leads us back to the study of Birkinshaw, Hood and Jonson (1998), in which 
Entrepreneurial Orientation appeared as a determinant in the formation of the organizational resources for Initiatives. One can only deduct that among Brazilian MNEs' subsidiaries, Entrepreneurial Orientation, similarly to what happened among subsidiaries of multinationals from developed countries, is a key element for the formation and development of resources and capacities that may come to increase the formation of Initiatives. The lack of operationalization of the Resources variable thus appears to be one of the limitations of the results presented herein.

Another consideration to be made is that Integration and Entrepreneurial Orientation have not been leading to the Initiatives that could reasonably be expected from the subsidiaries, because most Brazilian MNEs' headquarters presumably are not yet prepared to properly manage subsidiaries' portfolios and the knowledge flows that would result from corporate network units' integration, originating from Internal Market Initiatives. Thus, as subsidiaries are pressured into producing results and lack suitable help from their headquarters, they help themselves to the business environment of their host country to take the initiatives necessary to achieve the results that will ensure the sustainability of their business in the host country.

On the other hand, Entrepreneurial Orientation is not fully carried out due to the low autonomy of BrMNEs' subsidiaries. The limited Autonomy of most subsidiaries ends up leading directly to limited insertion into Business Networks and to a low degree of Initiative. Only those subsidiaries that manage to overcome this barrier of lack of freedom and to work in a more integrated fashion with their local and global partners are able to generate major Initiatives for the MNEs competitiveness.

Therefore, the fact that the Initiative is not directly related with Autonomy can be explained by the fact that Autonomy has a strongly indirect, rather than direct, impact upon initiatives. In other worlds, Autonomy is important for inserting Brazilian MNEs' subsidiaries into the business networks abroad, which then determine the subsidiaries' Initiatives.

Nevertheless, the discussion is not limited to this finding only. The high Entrepreneurial Orientation found in subsidiaries and the lack of a direct relation between Autonomy and Initiatives, coupled with the dependence of the Initiatives on the Local Context and Business Network factors suggest a structural arrangement that is different from what was seen among the early movers' subsidiaries: rebellious subsidiaries, discussed below.

\section{Particular characteristics of Brazilian MNES}

Studies have analyzed the isolation of subsidiaries as a negative aspect of the relation between them and headquarters (MONTEIRO, ARVINDSSON, BIRKINSHAW, 2007), which presumably would affect those subsidiaries that contributed little to the corporation's global results, even if in their host countries they produced satisfactory results.

Thus, in dealing with the subsidiaries of emerging countries, one possibility concerns what one can call rebellious subsidiaries that take initiatives based on their business environment connections (Local Context and Business Networks), regardless of their headquarters' consent or delegation of Autonomy (low in the results presented here). This possibility is underscored by the results, which show that the subsidiaries have high entrepreneurial capacity, combined with only low Autonomy granted by their headquarters.

The notion of rebellious subsidiaries is somehow aligned to the evolutionary role of subsidiaries that Birkinshaw and Hood (1998) called "Subsidiary-driven charter extension". In this process, headquarters are averse to granting credit for the subsidiary to carry out any activity with higher strategic responsibility. Thus, the acquisition of greater responsibility is solely under the subsidiaries' responsibility and they may, even going against their headquarters' wishes, engage in market initiatives largely connected with the local or global market. The interesting element here is that subsidiary initiative, in this process may materialize without any headquarters awareness of it. This would be the first type of rebelliousness, found in the study of Birkinshaw and Hood (1998).

Nevertheless, this process tends to occur among those subsidiaries that have more autonomy (BIRKINSHAW, HOOD, 1998). In the case of the subsidiaries of Brazilian MNEs, the results showed that there are very few with sufficient Autonomy to undertake such activities. On the contrary, the Brazilian MNEs' subsidiaries are characterized by a high entrepreneurial orientation but low autonomy. Thus, for most of them, the only means of taking advantage of market initiatives is to rebel against their low autonomy and run the risk of undertaking their initiatives solely under their own steam. This would be the second type of subsidiary rebelliousness, which appears to be especially characteristic of Brazilian MNEs' subsidiaries.

In sum, for most of the subsidiaries of Brazilian MNEs, the only way to create and develop initiatives would be through embracing rebelliousness relative to the multinationals' structural configuration. 


\section{LIMITATIONS AND FUTURE RESEARCH}

To conclude this paper, it is also important to emphasize aspects that could constitute pathways for future research on the internationalization process of Brazilian MNEs from emerging markets. The presented results that subsidiary initiative are still limited are aligned with the literature in the field, as it is expected that firms in the initial stages of internationalization focus more on headquarters' initiatives and control over their subsidiaries. In this sense we can propose that these Brazilian MNEs are still far from being organized as differentiated network under a transnational strategy and an important challenge for these firms is 'skipping stages' and moving faster to an approach in which they can have the best from the potential of each subsidiary in the global corporate network, and this can be done with and adequate management of subsidiaries' portfolio. The high degree of integration in this survey also calls the attention as it is combined with the previously cited lack of integration. We can suppose that the necessary corporate integration, when exaggerated, can suffocate the initiatives of the subsidiaries and a recommendation to these firms is also discover the ways to deal with the necessary trade-off control-autonomy in a way in which each subsidiary perform as it best to improve corporate results. Finally, the concept of rebellious subsidiaries, that take initiatives based on their business environment connections, regardless of their headquarters' consent or delegation of autonomy, demands more research in order to clarify its implications for theory and practice of international business.

\section{REFERENCES}

ANDERSSON, U; FORSGREN, M. Creation and diffusion of competence in MNCs structures, ties and resources at the subsidiary level. In HADJIKHANI, Amjad; LEE, Joong-Woo; JOHANSON, Jan. (Eds) Business networks and international marketing. Soul: Doo Yang, 2006. p. 333-346.

ANDERSSON, U; FORSGREN, M; HOLM, U. The strategic impact of external networks: subsidiary performance and competence development in multinational corporation. Strategic Management Journal, v. 23, p. 979-996, 2002

BARTLETT, C.A; GHOSHAL, S. Transnational Management. 2nd. ed. Boston: McGraw-Hill,1998.
BARTLETT, C. A; GHOSHAL, S. Going global: lessons from late movers. Harvard Business Review, mar-abr. 2000

BCG. The 2009 BCG 100 new global challengers. The Boston Consulting Group, jan. 2009.

BIRKINSHAW, J. Entrepreneuship in multinational corporations: the caracteristics of subsidiary initiatives. Strategic Management Journal, v. 18, p. 207-229, 1997.

BIRKINSHAW, J. How multinational subsidiary mandate are gained and lost. Journal of International Business Studies, v. 27, n. 3, p. 467-495, 1996.

BIRKINSHAW, J; FRY, N. Subsidiary initiatives to develop new markets. Sloan Management Review. Cambridge, v. 39, n. 3, p. 51-61, Spring, 1998

BIRKINSHAW, J; HOOD, N. Multinational subsidiary evolution: capability and charter change in foreign-owed subsidiaries companies. Academy of Management, v. 23, p., 773-795, 1998.

BIRKINSHAW, J; HOOD, N. An empirical study of development process in foreign-owed subsidiaries in Canada and Scotland. Management International Review, v. 37, n. 4, p. 339-364, 1997.

BIRKINSHAW, J; HOOD, N; JONSSON, S. Building firm-specific advantages in multinational corporations: the role of subsidiary initiative. Strategic Management Journal, 19: 221-241, 1998.

BJORKMAN, I; FORSGREN, M. Nordic international business research: a review of its development. International Studies of Management and Organization, v. 30, n. 1, p. 6-25, 2000.

BOWER, J. L. Managing the resource allocation process. [S.1.]: Richard D. Irwin, 1970

BURGELMAN, R. A. A Process Model of Internal Corporate Venturing in the Diversified Major Firm. Administrative Science Quarterly, v.28, p.223244, 1983.

CUERVO-CAZURRA, A. The internationalization of developing country MNEs: the case of Multilatinas. Journal of International Management, v. 14, n. 2, p. $138-154,2008$

DUNNING, J. Multinational enterprises and the global economy. Workhingan: Addison-Wesley, 1993

FILION, L. J. Entendendo os intraempreendedores como visionistas. Revista de Negócios. Blumenau, v. 9, n. 2, p. 65-80, 2006 
FLEURY; M. T; FLEURY, A. F; OLIVEIRA JR, M. M; BORINI, F. Estratégias das empresas multinacionais brasileiras. Ginebra. Disponível em http:// www.ginebra.incubadora.fapesp.br. Acesso em nov. 2007.

FROST, T. The Geographic sources of foreign subsidiaries innovations. Strategic Management Journal, v. 22, p. 101-123, 2001.

FROST, T; BIRKINSHAW, J; ENSIGN, P. Centers of excellence in multinational corporations. Strategic Management Journal, v. 23, p. 997-1018, 2002.

HAIR, J. F; BLACK, B; BABIN, B; ANDERSSON, R. E; TATHAM, R. L. Multivariate data analysis. 6th ed. Upper Saddle River, NJ: Prentice Hall, 2005.

HOLM, U; PEDERSEN, T. Dilemma of centres of excellence: contextual creation of knowledge versus global transfer knowledge. Disponível em http:// web.cbs.dk/departments/int/publications/wp_2000/wp8-2000_tp.pdf. Acesso em 03.08.2005

JOHANSON, J; MATTSSON, L.-G. Internationalisation in industrial system - a network aproach. In: HOOD, N; VAHLNE, J.-E. (Eds) Strategies in global competition. [S.1.]: Croom Helm, 1998.

JOHANSON, J; VAHLNE, J. E. The internationalization process of the firm: a model of knowledge development and increasing foreign market commitments. Journal of International Business Studies, v. 8, n. 1, p.23-32, 1977.

LIU, H; LI, K. Strategic implications of emerging Chinese multinationals: the Haier case study. European Management Journal, v. 20, n. 6, p. 699-706, 2002.

LUO, Y; TUNG, R. International expansion of emerging market enterprises: a springboard perspective. Journal of International Business Studies, v. 38, p. 481-498, 2007.
MONTEIRO, L; ARVIDSSON, N; BIRKINSHAW, J. knowledge flows within multinational corporations: explaining subsidiary isolation and its performance implications. Organization Science, v. 18, n. 7, 2007.

NOHRIA, N; GHOSHAL, S. The differentiated network: organizing multinational corporations for value creation. San Francisco: Jossey-Bass, 1997.

PATERSON, S. L; BROCK; D. M. The development of subsidiary-management research: review and theoretical analysis. International Business Review, v. 11, p. 139-163, 2002.

PORTER, M. E. The competitive advantage of nations. New York: Free Press, 1990.

RAMAMURTI, R. What have we learned about EMNEs. In: RAMAMURTI, R; SINGH, J. (eds) Emerging multinationals from emerging markets. Cambridge, UK: Cambridge University Press, 2008.

SANTISO, J. The emergence of latin multinationals. [S.1.]: OECD Development Centre. EmNet, 2007.

SULL, D; ESCOBARI, M. Sucesso made in Brazil: o segredo das empresas brasileiras que dão certo. Rio de Janeiro, Elsevier, 2004.

VERNON, R. International investments and international trade in the product cycle. Quarterly Journal of Economics, v. 80, p. 190-207, 1966.

WERNER, S. Recent developments in international management research: a review of 20 top management journals. Journal of Management, v. 28 , n. 3, p. 277-305, 2002. 